\title{
Literasi Zakat: Interpretasi Masyarakat Terhadap Kewajiban Membayar Zakat
}

\author{
Uswatun Khasanah', Muhammad Maghfur ${ }^{2}$, Moh. Nurul Qomar3 \\ 1,2,3 Institut Agama Islam Negeri Kudus \\ 1,2,3 Jl. Conge Ngembalrejo Bae Kudus \\ Email: mnqomar@iainkudus.ac.id
}

\begin{abstract}
Abstrak
Secara nasional gap potensi zakat dengan realita zakat benar-benar terjadi, salah satu masalahnya adalah literasi zakat yang rendah. Penelitian ini berusaha mengkaji tingkat literasi zakat pada ruang lingkup komunitas, yaitu di Dukuh Krajan Desa Mayonglor Kabupaten Jepara. Fokus pada penelitian ini adalah tingkat pemahaman masayarakat terhadap kewajiban membayar zakat. Dalam penelitian ini digunakan metode kualitatif, adalah suatu data yang diperoleh dengan mengkaji dan upaya menggali fenomena dalam masyarakat sebagai sumber data secara objektif di lapangan. Peneliti menggunakan wawancara, observasi dan dokumentasi dalam teknik pengumpulan data. Hasil penelitian ini menunjukkan masyarakat Dukuh Krajan memahami pengetahuan dasar zakat cukup baik, meskipun dibutuhkan penyuluhan agama dan bukti zakat produktif sebagai upaya peningkatan literasi zakat lebih baik lagi.
\end{abstract}

Kata Kunci: Literasi zakat, Pengetahuan dasar zakat, Dukuh Krajan Jepara

\begin{abstract}
Nationally the gap of zakat potential with the reality of zakat really happens, one problem is low zakat literacy. This research seeks to examine the level of zakat literacy in the community's scope, namely in Dukuh Krajan Mayonglor Village Jepara Regency. Focus on this research is the level of understanding of society towards the obligation to pay zakat. In this study used a qualitative method, is a data got by reviewing and efforts to explore phenomena in society as an aim data source in the field. Researchers use interviews, observations and documentation in data collection techniques. The results showed that the community of Dukuh Krajan understands the basic knowledge of zakat well, although it takes religious counseling and evidence of productive zakat as an effort to improve zakat literacy even better.
\end{abstract}

Keywords: Literacy of Zakat, Knowledge of Zakat basic, Dukuh Krajan Jepara 


\section{PENDAHULUAN}

Dilihat dari segi pembangunan kesejahteraan umat, zakat adalah ibadah māliyah ijtimåiyah yang memiliki posisi sangat penting, strategis dan menentukan. Sebagai suatu ibadah yang pokok, zakat sangat asasi dalam Islam dan termasuk salah satu rukun (rukun ketiga) dari lima rukun Islam.

Zakat adalah kadar harta tertentu yang diberikan kepada yang berhak menerimanya, dengan berbagai syarat, semata-mata mencari ridha Allah swt (Wahardjani dkk, 2000). Zakat selain berdimensi ibadah ritual, juga memiliki dimensi sebagai amal ibadah sosial yang inklusif. Sebagai praktek yang telah melembaga dalam kehidupan masyarakat muslim, zakat telah mendukung kehidupan ekonomi, sosial dan politik umat Islam. Bahkan dalam konteks Indonesia zakat juga diharapkan menjadi pilar yang dapat menopang kesejahteraan umat dan bangsa.

Untuk melaksanakan pengelolaan zakat, maka pemerintah mengeluarkan UndangUndang Republik Indonesia Nomor 38 Tahun 1999 yang diamandemen dengan UndangUndang Nomor 23 Tahun 2011 Tentang Pengelolaan Zakat. Bersadarkan Undang-Undang zakat tersebut yang dimaksud pengelolaan zakat ialah kegiatan perencanaan, pelaksanaan, dan pengoordinasian dalam pengumpulan, pendistribusian, dan pendayagunaan zakat (Undang-Undang Pengelolaan Zakat, 2011). Peran yang utama dalam implementasi ini terletak pada keberadaan lembaga zakat yang profesional. Dengan mengakomodasi prinsipprinsip manajemen, diharapkan pendayagunaan filantropi Islam ini dapat maksimal.

Dana zakat yang dikelola dengan baik dan benar akan menciptakan kesejahteraan di masyarakat terkhusus kaum dhuafa yang mengalami kesulitan dalam masalah perekonomian. Tema kesejahteraan masih menjadi kajian yang menarik dalam studi ekonomi Syariah. Kegiatan ini kemudian mentransmisikan entitas kesejahteraan dari berbagai puzzle pemikiran Islam. Islam sebagai way of life secara pro aktif memberikan wadah tersendiri untuk menjamin distribusi hak dan kewajiban, dalam bentuk zakat, infak, shodaqah dan wakaf(Dewi, 2017).

Lazisnu sebagai salah satu Lembaga amil zakat misalnya, melalui program NU-Preneur berusaha meningkatkan kemandirian ekonomi para dhuafa yang ingin merubah nasibnya menjadi lebih baik. Kegiatan ini dilakukan dalam bentuk pemberian pinjaman modal dan bantuan barang yang dibutuhkan dalam membuka usaha kepada para mustahik atau dhuafa (Chotimah, 2020).

Literasi pada tingat nasional diakui masih rendah dan perlu dikembangkan model maupun inovasi dalam pengembangan filantropi islam. Meskipun begitu dibutuhkan pembuktian melalui penelitian tingkat literasi zakat pada sebuah komuninas berbasis islam. Penelitian Mukaromah dan Anwar (2021) tentang tingkat literasi zakat kontemporer pada 
pondok pesantren salaf. Hasilnya menunjukkan santri pondok salaf mengenal zakat kontemporer hanya pada istilah zakat profesi.

Selanjutnya penelitian ini dikembangkan pada tingkat literasi zakat pada ruang lingkup komunitas yang lebih besar dibanding pesantren, yaitu di Dukuh Krajan Desa Mayonglor Kabupaten Jepara. Fokus pada penelitian ini adalah tingkat pemahaman masayarakat terhadap kewajiban membayar zakat.

\section{KAJIAN TEORITIS}

\section{Konsep Dasar Zakat}

Makna zakat jika ditinjau dari lisan al-Arab dari sudut bahasanya, zakat berarti suci, tumbuh, berkah, dan terpuji. Semuanya digunakan di dalam al-Quran dan hadits (Qardhawi, 2002). Sedangkan menurut Undang-Undang No. 23 tahun 2011 pasal 1, Zakat adalah harta yang wajib dikeluarkan oleh seorang muslim atau badan usaha untuk diberikan kepada yang berhak menerimanya sesuai dengan syariat Islam (Undang-Undang Pengelolaan Zakat, 2011).

Zakat adalah salah satu dari kesekian ajaran sosial Islam yang berorientasi pada kemaslahatan kemanusiaan. Peran zakat dalam mengentaskan kemiskinan adalah peran yang tidak bisa dipungkiri keberadaannya, baik dalam kehidupan muslim atau kehidupan lainnya. Khalayak umum hanya mengetahui bahwasanya tujuan zakat yang utama adalah mengentaskan kemiskinan dan juga membantu para fakir miskin (Qardhawi, 2002). Untuk mewujudkan peran zakat dalam mengentaskan kemiskinan, maka pengelolaan zakat yang profesional menjadi syarat utama.

Sehingga dapat disebut bahwa zakat adalah suatu bagian dari harta yang telah ditetapkan oleh Allah swt kepada 8 asnaf sebagai dijelaskan dalam Alquran surat at-Taubah ayat 103:

"Ambillah zakat dari sebagian harta mereka, dengan zakat itu kamu membersihkan dan mensucikan mereka dan mendoalah untuk mereka. Sesungguhnya doa kamu itu (menjadi) ketenteraman jiwa bagi mereka. Dan Allah Maha Mendengar lagi Maha Mengetahui." (QS. 9:103)

Selain ayat tersebut di atas, terdapat riwayat dari hadist Rosulullah yang mengutus Muadz bin Jabal ke Yaman dan salah satu tugas nya adalah menjadi Amil (Badan Amil Zakat Nasional, 2019). Zakat mempunyai kontribusi yang signifikan dalam peradapan Islam. Peran zakat dalam sejarah peradaban Islam sangat nyata dan kentara dalam memberantas kemiskinan dan menjadi pondasi ekonomi negara (Supriyadi, 2020).

\section{Penelitian terdahulu}


Hasil penelitian menunjukkan bahwa terdapat gap antara potensi dengan realisasi zakat di Indonesian pada tahun 2014-2018. Penyebab ketimpangan tersebut adalah karena masyarakat belum sepenuhnya percaya terhadap lembaga amil zakat. Oleh karenanya, banyak masyarakat yang akhirnya tidak menyalurkan zakatnya via lembaga amil akan tetapi langsung kepada mustahiq disekitarnya(Afiyana et al., 2019).

Tugas dan tantangan berat bagi Baznas dan LAZ untuk lebih aktif lagi untuk melakukan sosialisasi dan berperan aktif dalam kegiatan social. Beberapa penelitian lain yang bertemakan literasi zakat antara lain penelitian Rofiqoh et al., (2018) berusaha meningkatkan literasi zakat melalui penyaluran zakat produktif berkolaborasi dengan BMT-Muda IZI. Penelitian setipe dilakukan (Sardiana, 2018), (Yusfiarto et al., 2020) dan (Mukaromah \& Anwar, 2021).

Sedangkan pada penelitian ini bertujuan untuk mengkaji lebih dalam masalah literasi zakat pada tingkat desa dalam sudut pandang tingkat pemahaman masyarakat terhadap kewajiban membayar zakat.

\section{METODE PENELITIAN}

Dalam penelitian ini digunakan metode kualitatif, adalah suatu data yang diperoleh dengan mengkaji dan upaya menggali fenomena dalam masyarakat sebagai sumber data secara objektif di lapangan tentang pemahaman Mayarakat Dukuh Krajan Desa Mayong lor terhadap kewajiban zakat. Peneltian ini membahas tentang tingkat pemahaman Masyarakat Dukuh Krajan Desa Mayong lor terhadap pelaksanaan zakat.

Merujuk pada indeks literasi zakat (Badan Amil Zakat Nasional, 2019), maka komponen pada pertanyaan ini hanya masuk pada dimensi pengetahuan dasar tentang zakat. Penentuan lokasi penelitian ini pertimbangannya bahwa tingkat ekonomi masyarakat Dukuh Krajan lebih tingggi dibanding desa lainnya, hampir semua masyarakat di Dukuh krajan adalah pengrajin genteng dan pengusaha genteng.

Pada penelitian ini ditetapkan 50 responden yang terdiri dari berbagai latar belakang, antara lain: a. Masyarakat muslim, b. Akademisi c.Umat islam yang belum berzakat d. Umat islam yang sudah berzakat. Sedangkan Teknik pengumpulan data dilakukan dengan metode wawancara, observasi, dan dokumentasi. Dalam hal observasi langsung yaitu melakukan pengamatan ke Dukuh Krajan Desa Mayonglor mengenai pemahaman Masyarakat Dukuh krajan terkait kewajiban berzakat, peneliti membagikan quesioner kepada pada masyarakat di Dukuh Krajan Desa Myonglor.

\section{HASIL DAN PEMBAHASAN}

\section{Profil Dukuh Krajan Desa Mayonglor Jepara}

JISFIM: Journal of Islamic Social Finance Management, Volume 2, No 1 Tahun 2020 http://jurnal.iain-padangsidimpuan.ac.id/index.php/JISFIM 
Desa Mayonglor terletak di sebelah utara berbatasan dengan Desa Pelemkerep, sedangkan disebelah selatan berbatasan dengan desa Mayong Kidul, pada sebelah barat berbatasan dengan Desa Tiga Juru, dan disebelah timur berbatasan dengan Desa Pringtulis dan Tunggul.

Desa Mayonglor merupakan salah satu Desa dari 18 Desa yang berada di kecamatan mayong kabupaten Jepara, dengan jumlah seluruh penduduk yaitu 12.876 jiwa dengan masing-masing 6.496 jiwa laki-laki dan 6.380 jiwa perempuan, yang terdiri dari 4.756 jiwa laki-laki dewasa, 1.740 jiwa anak-anak dan 4.808 jiwa perempuan dewasa, 1.572 anak-anak. Di Desa mayonglor terdapat beberapa Dukuh, yaitu:
a) Dukuh Bendowangen
b) Dukuh Krajan
c) Dukuh Gleget lor
d) Dukuh Gleget Kidul
e) Dukuh Karang Panggung

\section{a. Agama}

Ditinjau dari segi agama, mayoritas penduduk di Dukuh Krajan Desa Mayonglor beragama islam. Sebagian besar masyarakat Dukuh Krajan mendalami kegiatan keagamaan, contoh musholla atau masjid digunakan sholat lima waktu, sholat jumat dan pengajian diharihari tertentu.

\section{b. Sosial Budaya dan Adat Istiadat}

Kegotong royongan masyarakat sangat jelas dijumpai. Hal ini dipengaruhi oleh adanya rasa kebersamaan diantara mereka. Namun demikian, adat istiadat yang turun temurun masih sangat erat dipegang oleh sebagian besar masyarakat Kecamatan Marittengngae, hal ini dapat dilihat dari acara-acara adat yang dilakukan masyarakat.

\section{c. Keadaan Sosial Ekonomi}

Keadaan sosial ekonomi masyarakat Dukuh krajan Desa Mayonglor sebagaimana kita ketahui bersama bahwa Dukuh Krajan merupakan salah satu Dukuh pengrajin genteng di Kecamatan mayong, dan tak banyak juga yang berprofesi sebagai guru, dan pengusaha. Keadaan sosial ekonomi yang mapan dapat terlihat pada pesatnya perkembangan perekonomian di Dukuh krajan.

\section{Literasi Zakat Masyarakat Dukuh Krajan Desa Mayonglor Jepara}

\section{Zakat hanya sekedar diketahui}

Zakat merupakan salah satu rukun Islam yang wajib dilaksanakan, Kewajiban zakat sama halnya dengan kewajiban sholat. Di dalam Al-Qur'an terdapat 32 ayat yang memerintahkan sholat dan zakat secara beriringan. 
Menurut istilah, zakat adalah pemberian harta dengan kadar tertentu kepada yang berhak sebagai ibadah wajib kepada Allah swt. Kesadaran masyarakat dalam memahami hukum menunaikan zakat sangat penting.

Pada realita yang ada di lapangan menunjukkan bahwa masyarakat Dukuh Krajan Desa Mayonglor tentang pemahaman zakat hanya sekedar mengetahui secara umum atau sudah familiar, artinya zakat tidak asing lagi di telinga warga Dukuh Krajan, akan tetapi masyarakat belum paham apa fungsi tujuan dan manfaat zakat bagi orang yang mengeluarkan zakat, dan orang yang menerima zakat. Hal tersebut dapat dibuktikan melalui jawaban responden atas pertanyaan-pertanyaan yang diajukan, diantaranya adalah sebagai berikut:

Tabel 1

Pemahaman terhadap Pengertian Zakat

Pilihan Jawaban

Pemilih (orang)

\begin{tabular}{lr}
\hline a. Sekedar mengetahui saja & 15
\end{tabular}

b. Paham dan mengetahui tujuan dan fungsinya 30

c. Kurang paham 5

d. Tidak tahu -

$\begin{array}{ll}\text { Jumlah } & 50\end{array}$

Dari data yang ditampilkan Tabel 1 menunjukkan bahwa tingkat pemahaman masyarakat tentang zakat masih tergolong cukup, hal ini dituunjukkan pada responden yang memilih jawaban (b) paham dan mengetahui tujuan dan fungsinya sebanyak 30 responden yang memilih, mengingat Jepara dikenal sebagai masyarakat agamis tentu pemahaman tentang zakat bukan barang asing lagi. Akan tetapi masih dijumpai masyarakat yang menjawab sekedar mengetahui dan kurang paham secara akumulasi hampir sebanding dengan yang paham akan zakat. Hal ini menunjukkan bahwa masyarakat mengenal zakat masih pada tataran fikih.

\section{Ulama sebagai rujukan dalam menghitung zakat}

"Bagaimana menghitung kadar harta yang wajib dikeluarkan sebagai zakat", dari pertanyaan tersebut diperoleh pilihan jawaban dari responden sebagai berikut: 
Tabel 2

Cara Menghitung Kadar Harta yang Wajid Dikeluarkan Sebagai Zakat

Pilihan jawaban

Pemilih

(orang)

a. Meminta jasa BAZ untuk menghitungkan besarnya zakat 0 yang wajib dikeluarkan

b. Meminta jasa ulama untuk menghitungkan besarnya 38 zakat yang wajib dikeluarkan

c. Menduga-duga saja besarnya nilai zakat yang harus 9 dikeluarkan

d. Menghitung sendiri secara benar sesuai dengan 3 ketentuan islam

Berdasarkan variasi jawaban yang diberikan responden pada tabel 2 menjadi indikator bahwa posisi Lembaga pengelola zakat belum diterima atau belum dikenal oleh masyarakat Dukuh Krajan terbukti responden tidak menjawab BAZ sebagai rujukan untuk menghitung zakat. Di sisi lain tokoh agama, kiai atau ulama masih mendominasi sebagai rujukan dalam menghitung zakat. Hal ini dikarenakan di Dukuh Krajan sendiri tidak terdapat LAZ yang dapat dimintai bantuan untuk menghidung berapa kadar zakat yang harus dikeluarkan oleh masyarakat setempat. Interpretasi lain dari tabel di atas peneliti mempertanyakan kedalaman pemahaman masyarakat Dukuh Krajan, hal ini terlihat jawaban pada pernyataan (d) terhitung rendah hanya 3.

\section{Penyaluran harta zakat hanya di salurkan kepada mustahik secara langsung}

Pada realita masyarakat Dukuh Krajan Desa Mayonglor penyaluran zakat mereka hanya disalurkan langsung kepada para mustahik di sekitar kediaman mereka, sebagaimana seperti hasil petikan wawancara dengan warga yang berprofesi sebagai pengusaha genteng di Dukuh Krajan Desa Mayonglor bapak H. Nor Said memberikan pernyataan sebagai berikut: "selama ini dimana bapak salurkan zakat perniagaan tersebut?". Dengan jawaban yang dilontarkan oleh bapak H. Nor Said (Wawancara Dengan Responden Pengusaha Genteng, 2021a) adalah sebagai berikut:

"Selama saya menjalankan bisnis usaha ini saya salurkan di masyarakat sekitar saya yang kurang mampu, tak terkadang juga saya berikan kepada masjid atau musholla atau madrasah yang membutuhkan dana untuk pembangunan" 
Responden lain, seorang pengrajin genteng, bapak Sudarno (Wawancara Dengan Responden Pengusaha Genteng, 2021b), mengatakan sebagai berikut:"Karena di Dukuh Krajan ini tidak ada lembaga resmi yang menangani Zakat, jadi saya salurkan zakat maal saya langsung kepada mereka yang membutuhkan, begitu juga dengan zakat fitrah, saya juga langsung menyalurkannya kepada pada mustahik di dekat rumah saya"

Dari hasil petikan wawancara dengan warga menunjukkan bahwa cara penyaluran zakat kepada yang berhak sudah tepat, akan tetapi ada sedikit kesalahan dimana zakat tidak boleh untuk pembangunan madrasah ataupun pembangunan masjid karena sudah ada ketentuannya yang berhak menerima zakat.

Dua jawaban di atas adalah jawaban yang mendominasi dari 50 responden. Interpretasi dari jawaban tersebut menunjukkan bahwa pengetahuan dasar zakat sudah baik, Pada aspek ketertarikan membayar zakat di lembaga formal sudah ada, namun apa daya keterjangkuan lembaga amil zakat di Dukuh Krajan belum tersedia. Untuk itu urgensi masjidmasjid di desa untuk mendaftarkan diri sebagai unit pengelola zakat dapat sebagai fasilitator antara Baznas dan masyarakat desa.

\section{Penyaluran harta zakat berupa uang tunai dan kebutuhan pokok}

Setelah wawancara dengan warga, hamper semua warga menyalurkan zakatnya ada yang berupa uang tunai da nada juga yang memberikan berupa kebutuhan pokok seperti beras. Sebagaimana petikan wawancara dengan ibu Hj. Masyuni (Wawancara Dengan Responden, 2021a) dengan tanggapan sebagai berikut:

"Saya mengeluarkan zakatnya sesuai dengan zakat apa yang saya keluarkan, semisal saya sedang panen besar ya saya berarti harus mengeluarkan zakat pertanian, itu biasanya yang saya berikan berupa beras, kalau saya sedang zakat mall ya saya berikan berupa uang, kalo pas menjelang lebaran kadang juga saya berikan berupa pakaian, seperti baju koko, peci, sarung."

Dilanjut dengan warga lain yang mendapat jatah pembagian uang zakat beserta sarung, dan baju koko atas nama bapak Sunardi (Wawancara Dengan Responden, 2021b), dengan komentar:

"Setiap tahun Alhamdulillah saya dapat jatah dari beberapa dermawan yang memberikan sedikit rezeki serta baju lebaran buat saya, tentun saya sangat senang masih ada yang memperhatikan kami."

Secara umum penyaluran zakat masyarakat Dukuh sudah dilaksanakan, meskipun dengan metode langsung kepada tetangga dan saudara yang dinilai berkategori 8 asnaf. 


\section{Peningkatan literasi zakat masyarakat Dukuh Krajan}

Zakat merupakan salah satu unsur dari sifat kedermawaan dalam konteks masyarakat muslim, sebagai salah satu unsur pokok bagi tegaknya syariat Islam. Oleh sebab itu, hukum zakat adalah wajib atas setiap muslim yang telah terpenuhi syarat-syarat tertentu. Zakat termasuk dalam dalam kategori ibadah (seperti shalat,haji, dan Puasa) yang telah diatur secara rinci dan paten berdasarkan Al-Qurean dan As-Sunnah, sekaligus merupakan amal sosial kemasyarakatan dan Kemanusiaan yang dapat berkembang sesuai dengan perkembangan umat manusia.

Dari data di atas, dapat kita simpulkan bahwasannya pemahaman tentang pentingnya zakat dikalangan masyarakat Dukuh Krajan Desa Mayonglor sudah cukup baik, hanya saja masih perlu penyuluhan tentang apa tujuan dan fungsi zakat baik bagi muzakki ataupun untuk mustahik. Sedangkan untuk strategi penyaluran zakat dapat diperbaiki dengan ikut andilnya pemerintah mendirikan lembaga zakat untuk mempermudah masyarakat setempat dalam pembayaran mau penyaluran harta zakat.

\section{KESIMPULAN}

Dari paparan di atas dapat disimpulkan bahwa Pengetahuan tentang dasar zakat masyarakat Dukuh Krajan masih bersifat minim dan berbasis pada fikih klasik. Pemahaman yang dimiliki belum sampai pada penghitungan harta zakat, terbukti masih meminta bantuan ulama. Meskipun menurut peneliti menilai pemahaman tentang kewajiban membayar zakat cukup baik, namun diperlukan penyuluhan agama dan bukti real manfaat zakat produktif di Dukuh Krajan. Bagi peneliti selanjutnya diharapkan mampu membuat intrumen penelitian secara utuh dari dimensi dan variabel indeks literasi zakat yang telah diterbitkan oleh BAZNAS Pusat.

\section{DAFTAR PUSTAKA}

Afiyana, I. F., Nugroho, L., Fitrijanti, T., \& Sukmadilaga, C. (2019). Tantangan pengelolaan dana zakat di indonesia dan literasi zakat Tantangan pengelolaan dana zakat di indonesia dan literasi zakat. Akuntabel, 16(2). https://doi.org/10.29264/jakt.v16i2.6013

Badan Amil Zakat Nasional, P. K. S. (2019). Indeks Literasi Zakat. Pusat Kajian Strategis Badan Amil Zakat Nasional (Puskas BAZNAS).

Chotimah, H. (2020). Upaya Peningkatan Kemandirian Ekonomi Umat Melalui NU-Preneur Pendahuluan Pembangunan ekonomi merupakan suatu keharusan jika suatu negara ingin meningkatkan taraf hidup dan kesejahteraan rakyatnya . Dengan kata lain , pembangunan ekonomi merupakan upaya s. JIES: Journal of Islamics Studies, 1(2), 6069.

JISFIM: Journal of Islamic Social Finance Management, Volume 2, No 1 Tahun 2021 http://jurnal.iain-padangsidimpuan.ac.id/index.php/JISFIM 
Dewi. (2017). Strategi Pendayagunaan Zakat Produktif Untuk Pemberdayaan Kesejahteraan Mustahiq (Studi Kasus Pada Lazis NU Kabupaten Banyumas). Jurnal Penelitian Agama, 18(2), 257-289.

Wawancara dengan Responden Pengusaha Genteng, (2021) (testimony of H. Nor Said).

Wawancara dengan Responden, (2021) (testimony of Hj. Masyuni).

Mukaromah, S. A., \& Anwar, A. Z. (2021). Tingkat Literasi Zakat Kontemporer Pada Pesantren Salaf. JASNA:Journal for Aswaja Studies, 1(1), 51-63.

Qardhawi, Y. (2002). Teologi Kemiskinan: Doktrin dasar dan Solusi Islam atas Problem Kemiskinan. Mitra Pustaka.

Undang-Undang Pengelolaan Zakat, (2011).

Rofiqoh, S. N. I., Ala'uddin, M., \& Hasanah, N. (2018). STRATEGI FUNDRISING ZAKAT : LITERASI ZAKAT PRODUKTIF DAN ZAKAT PROFESI ( Studi Pada BMT MUDA Jatim Mitra Inisiatif Zakat Indonesia ). Annual Conference on Community Engagement, 557575.

Sardiana, A. (2018). Implementasi Literasi Keuangan Syariah Pada Alokasi Dana Ziswaf Masyarakat. Maqdis : Jurnal Kajian Ekonomi Islam, 3(2).

Wawancara dengan Responden Pengusaha Genteng, (2021) (testimony of Sudarno).

Wawancara dengan Responden, (2021) (testimony of Sunardi).

Supriyadi, A. (2020). el Barka: Journal of Islamic Economic and Business. El Barka: Journal of Islamic Economic and Business, o3(01), 110-136.

Wahardjani dkk. (2000). Fiqh Islam. PT Citra Karsa Mandiri.

Yusfiarto, R., Setiawan, A., \& Nugraha, S. S. (2020). Literacy and Intention to Pay Zakat : A Theory Planned Behavior View Evidence from Indonesian Muzakki. International Journal of Zakat, 5(1), 15-27. 